\title{
Diversity and seasonality of Scarabaeinae (Coleoptera: Scarabaeidae) in forest fragments in Santa Maria, Rio Grande do Sul, Brazil
}

\author{
PEDRO G. DA SILVA ${ }^{1,3}$, FERNANDO Z. VAZ-DE-MELLO ${ }^{2}$ and ROCCO A. DI MARE ${ }^{3}$ \\ ${ }^{1}$ Programa de Pós-Graduação em Ecologia, Departamento de Ecologia e Zoologia, \\ Universidade Federal de Santa Catarina, 88040-900 Florianópolis, SC, Brasil \\ ${ }^{2}$ Instituto de Biociências, Departamento de Biologia e Zoologia, Universidade Federal de Mato Grosso, \\ Avenida Fernando Corrêa da Costa, 2367, Boa Esperança, 78060-900 Cuiabá, MT, Brasil \\ ${ }^{3}$ Programa de Pós-Graduação em Biodiversidade Animal, Universidade Federal de Santa Maria, \\ Avenida Roraima, 1000, Camobi, 97105-900 Santa Maria, RS, Brasil \\ Manuscript received on April 13, 2012; accepted for publication on October 11, 2012
}

\begin{abstract}
Scarabaeinae specimens were collected with the use of pitfall traps baited with human excrement, rotten meat and rotting banana, between May 2009 and April 2010, in three forest fragments in Santa Maria, Rio Grande do Sul, Brazil: 'Morro do Elefante' (MOEL), 'Morro do Cerrito' (MOCE) and 'Campus da Universidade Federal de Santa Maria' (UFSM). A total of 19,699 individuals belonging to 33 species were collected. Canthidium aff. trinodosum Boheman, 1858, Canthon latipes Blanchard, 1845, Dichotomius assifer (Eschscholtz 1822), Eurysternus caribaeus (Herbst 1789), Canthidium sp. and Canthon lividus Blanchard, 1845, were the most abundant species. MOEL showed the greatest richness, MOCE the greatest abundance, while UFSM showed the lowest values of richness and abundance. The greatest similarity (qualitative and quantitative) was found between MOEL and MOCE, while the lowest occurred between MOCE and UFSM. Only $51 \%$ of the species were common to all three fragments. The richness and abundance of Scarabaeinae were positively correlated with the air temperature. The richness of the fragment decreased according to the smaller size and the greater degree of disturbance of vegetation structure.
\end{abstract}

Key words: Atlantic forest, dung beetles, Southern Brazil, species richness, temporal distribution.

\section{INTRODUCTION}

Human action has caused the reduction and loss of biodiversity (Favila and Halffter 1997, Medri and Lopes 2001, Halffter 2005, Verdú et al. 2007) because of habitats transformation, fragmentation and loss, the so-called 'erosion of biodiversity' (Marques et al. 2002). In Brazil, this action is more evident in the alteration and the decline of its forests (Fearnside 2005, Tabarelli et al. 2005), which retain

Correspondence to: Pedro Giovâni da Silva

E-mail: pedrogiovanidasilva@yahoo.com.br most of the Brazilian biodiversity (Costa et al. 2000, Myers et al. 2000, Costa et al. 2005, Giulietti et al. 2005, Mittermeier et al. 2005).

In Neotropical forests, the monitoring of these alterations has been investigated by using bioindicators (Brown-Jr. 1991, 1997, Halffter and Favila 1993, Favila and Halffter 1997, BrownJr. and Freitas 2000, Gardner et al. 2008). Among these, Scarabaeinae (Coleoptera: Scarabaeidae) has received special attention (Spector 2006) due to its strong relationship with the forest environment 
and mammals that live in these forests (Gill 1991, Halffter 1991) and because it has the necessary characteristics for this purpose (Favila and Halffter 1997, Spector 2006).

There are approximately 7,000 species of Scarabaeinae worldwide (Schoolmeesters et al. 2010), and the greatest diversity is concentrated in tropical forests and savannahs, forming a functionally and taxonomically well-defined community (Halffter and Edmonds 1982, Hanski and Cambefort 1991). In Brazil, these beetles are known as 'rola-bostas' because they make, roll and bury small portions of the ball-shaped food that serves as a substrate to lay their eggs and as food to the larvae (Halffter and Matthews 1966, Hanski and Cambefort 1991, Simmons and Ridsdill-Smith 2011).

The dung beetles are detritivorous and promote the removal from and re-entry of organic matter in the soil where they feed themselves in the nutrients' cycle (Halffter and Matthews 1966, Hanski and Cambefort 1991). Hence, they help clean the environment, and maintain and regulate the edaphic physical-chemical proprieties by burrowing, thus furnishing the soil with better aeration and hydration, as well as incorporating nutrients contained in dung, fruits and animal carcasses buried within the galleries (Halffter and Matthews 1966, Halffter and Edmonds 1982, Hanski and Cambefort 1991, Nichols et al. 2008).

Currently, Scarabaeinae beetles have been used in some countries (e.g. Australia, Brazil, Chile and the USA) for the control of bovine parasites (Waterhouse 1974, Bornemissza 1976, Flechtmann and Rodrigues 1995, Koller et al. 2007). The group has also been employed as an environmental indicator (Halffter and Favila 1993, Spector and Forsyth 1998, Davis et al. 1999, 2001, 2004, McGeoch et al. 2002, Spector 2006, Nichols et al. 2007, 2008), once these insects are very sensitive to changes in the ecosystem (Halffter and Favila 1993, McGeoch et al. 2002, Andresen 2003, Spector and Ayzama 2003, Larsen and Forsyth 2005, Gardner et al. 2008) and may respond differently to these changes, altering their abundance, richness and species composition.

Factors such as vegetation cover, vegetation type, fragmentation, habitat loss, physical structure and altitude of ecosystem, as well as human activity, influence the assembly of Scarabaeinae in different environments (Davis et al. 1999, Halffter and Arellano 2002, Escobar et al. 2007). Thus, many species are adapted to a particular type of habitat or food resource (Davis 1996), and human interference, which tends to alter the ecosystem, causes a major change in the assemblies, and may influence on the rareness and local loss of species (Davis and Philips 2005).

In Rio Grande do Sul there are two distinct biomes (Atlantic forest in the northern and the Pampa in the southern) and they have suffered great losses in area along decades because of the transformation of their respective ecosystems - forest and grassland (Bencke 2009, Instituto Brasileiro de Geografia e Estatística, 2009, Cordeiro and Hasenack 2009, Roesch et al. 2009). Contrastingly, in many regions of Rio Grande do Sul the data about most of invertebrates are still considered scarce (Bencke 2009, Roesch et al. 2009), even though there are reports about the high number of endemic species that dependent of one or both biomes, and about the present conditions of degradation of these biomes (Bilenca and Miñarro 2004, Bencke 2009, Overbeck et al. 2009, Roesch et al. 2009, Inventário Florestal Contínuo 2010).

Despite of the fact that invertebrates are mostly constituted by the biodiversity of terrestrial ecosystems, and are also important links in the trophic chain, the knowledge about Scarabaeinae is scarce in Rio Grande do Sul, being Lepidoptera and Hymenoptera the most in-depth species studied (Bencke 2009). Studies on beetles are still incipient in Rio Grande do Sul (see Audino et al. 2007, Moura 2003, 2007), and within the order, only Cerambycidae and Chrysomelidae have been well 
investigated (Moura 2003). Recently, Scarabaeinae has been the focus of studies in extreme south Brazil (Silva et al. 2008, 2009, Audino et al. 2011, Silva 2011), covering the 'Campanha' region of Rio Grande do Sul, within the Pampa biome. As well as many regions of Brazil, the state still needs further surveying and the data on the species derive mostly from old-fashioned literature and taxonomic studies of material in museums (Vaz-de-Mello 2000).

Therefore, this study aims at determining whether the Scarabaeinae assemblies are different in forest fragments with different levels of disturbance in Santa Maria, Rio Grande do Sul, Brazil. The temporal distribution of Scarabaeinae was correlated with climate variables in order to find possible links between them.

\section{MATERIALS AND METHODS}

\section{STUDY AREA}

The municipality of Santa Maria is located in the central portion of Rio Grande do Sul, with its major part within the domain of the Pampa biome and the northern part belonging to the Atlantic Forest biome (Marchiori 2009, Instituto Brasileiro de Geografia e Estatística 2010). The climate in Santa Maria is subtropical rainy and warm, Cfa according to the classification of Köppen-Geiger (Pell et al. 2007) in which the average annual precipitation is $1,700 \mathrm{~mm}$ and the average annual air temperature is $19^{\circ} \mathrm{C}$ (Instituto Nacional de Meteorologia 2010). Most of the municipality is constituted of grassland lowlands and the forest vegetation is restricted to watercourses and hillsides, the latter belonging to the Deciduous Forest of the 'Fralda da Serra Geral' (Pereira et al. 1989). The municipality is in the transition zone between 'Depressão Central' and 'Planalto Meridional Brasileiro', with altitudes ranging from 40 to $500 \mathrm{~m}$ above sea level. According to the Continuous Forest Inventory (Inventário Florestal Contínuo 2010), the city is located in an area of ecological tension, and is an important environment that is a receptor of species from both biomes within Rio Grande do Sul.

In order to conduct the study, three different non-contiguous forest habitats were chosen for the collection of Scarabaeinae beetles: a forest with highly preserved vegetation, a forest with intermediate level of alteration and a forest with intensive anthropogenic interference, with mass plantation of exotic trees. The main criterion for choosing the areas was the degree of internal and surrounding disturbance (transformation) of the forest for diverse purposes.

'Morro do Elefante' (MOEL). Located near the former primary school 'Cidade dos Meninos' (2940'33”S, 5343'14'W), it is a non-isolated remnant of the Seasonal Deciduous Forest of the escarpment of 'Planalto Médio Riograndense' or 'Fralda da Serra Geral' (Machado and Longhi 1990). At the base of its southern face, there are small areas within the forest cultivated with Pinus sp., Eucalyptus sp. and Citrus sp., and the cutting of trees in some properties, which are currently going through a process of regeneration. The total area of this forest fragment is around 729.3 ha even though a major part is in an area of difficult access, where the inclination is superior to $45^{\circ}$. The average altitude is $249 \mathrm{~m}$ (maximum of 465 $\mathrm{m}$ ) and within the forest there are some trails and clearings. The surrounding of the fragment is largely composed (at north and northwest) by a chain of other hills with similar forest vegetation, and other areas with farms with livestock and crops. It will be treated as forest area with a high level of preservation.

'Morro do Cerrito' (MOCE). Located at 'Centro

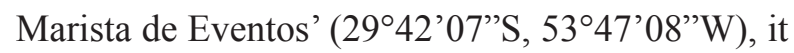
is an isolated remnant of Deciduous Forest of 'Serra Geral' and is part of 'Depressão Central' of Rio Grande do Sul (Pereira et al. 1989). Its approximate area is $141.5 \mathrm{ha}$, the average elevation is $169 \mathrm{~m}$, with intermediate level of transformation of its 
forest vegetation into fields, and residences. The number of neighbor fragments normally composed by native vegetation is high, but the mean distance among them is large, causing MOCE to become increasingly isolated. It will be treated as forest area with intermediate level of preservation.

'Campus da Universidade Federal de Santa Maria'(UFSM). It is a forest area with high level of disturbance (2943'27'S, 5343'29'W), currently constituted of a forest fragment with secondary native vegetation in the understory, the border and in smaller contiguous fragments, as well as mixed plantations of Pinus spp. and Eucalyptus spp. in the surrounding (Dambros et al. 2004, Madruga et al. 2007). The area size is approximately 35.2 ha, the average altitude is $95 \mathrm{~m}$ and there are buildings, grassland areas and crop areas in the surroundings. This fragment will be treated as forest area with high level of disturbance.

The distance between the fragments was calculated by using the software Google Earth, there being $6.8 \mathrm{~km}$ between MOEL and MOCE, $6 \mathrm{~km}$ between MOCE and UFSM, and $4.8 \mathrm{~km}$ between MOEL and UFSM (for more information, see Silva et al. 2012).

\section{SAMPLING METHOD}

The specimens were collected through the use of baited pitfall traps, once they correspond to the most efficient sampling method for the capture of most of this group (Lobo et al. 1988, Halffter and Favila 1993, Favila and Halffter 1997, Spector 2006). The traps were baited with human feces, chicken offal (heart) and banana (the two latter were rotten in plastic pots at ambient temperature for three days), corresponding to the insects' main diets: coprophagy, necrophagy and saprophagy (Halffter and Matthews 1966, Hanski and Cambefort 1991).

The traps consisted of a one-liter plastic container with $13 \mathrm{~cm}$ diameter and $10 \mathrm{~cm}$ height, buried with the edge kept at soil level to allow the insects fall (Lobo et al. 1988, Ausden 1996). A plastic bait-holder pot with smaller dimensions was put on a larger one in order to accommodate the baits. A solution of water, formalin (10\%) and detergent (neutral) was used inside the trap so as to capture and preserve the specimens. A total of 27 traps were distributed along three transects over $100 \mathrm{~m}$ distant from each other in each one of the fragments, and they were arranged in a triangle shape of two meters of side, containing the three kinds of baits used. Each transect contained three sets of three traps $30 \mathrm{~m}$ distant from each other. The samplings were collected between May 1, 2009 and April 30, 2010, in fortnightly collections. Thus, there were two collections every month, the first at the end of the first half, and the second at the end of the second half. The traps remained in the field during all time of duration of the study (for more information, see Silva et al. 2012).

The insects were captured and then transported in sealed plastic containers being properly labeled at the Laboratório de Biologia Evolutiva (LBEV) at Universidade Federal de Santa Maria, where they were sorted, counted, pre-identified and accommodated in entomological blankets and boxes, and in bottles with alcohol 70\%. The preidentification was carried out through the use of a key to genera of Scarabaeinae (Vaz-de-Mello et al. 2011) and their comparison with specimens that had already been deposited at the laboratory; and they were separated into morphospecies when unknown. Individuals of all species and morphospecies were then identified by the second author. The material is currently in the collections of Universidade Federal de Santa Maria, Santa Maria, RS and Universidade Federal de Mato Grosso, Cuiabá, MT.

\section{DATA ANALYSIS}

The assembly of Scarabaeinae was described in relation to richness ( $\mathrm{S}$ or alpha diversity), abundance $(\mathrm{N})$, species composition, similarity 
among fragments, species spatial exchange among habitats (beta diversity) and equitability (Moreno 2001). The distribution of abundance among species of Scarabaeinae was graphically compared among the fragments through ranks, where the relative abundance of each species was transformed into a logarithm of base $10(\mathrm{~N}$ +1 ) and arranged from highest to lowest value for each habitat (Verdú et al. 2007).

From the number of species and individuals obtained in each collection smoothed curves of sample sufficiency were made for each of the fragments (Mao Tau function of EstimateS software [Colwell 2004]) in order to verify the sample sufficiency. The estimated richness was obtained through the estimators Chao 1, Chao 2, Jackknife 1, Jackknife 2, and Bootstrap (and their confidence intervals at $95 \%$ ). The software EstimateS 7.0 was used for both analyses (Colwell 2004) with 500 replacement randomizations for the analysis of the estimators and no randomization for the construction of the accumulation curves (Colwell 2004).

The rarefaction method (Hulbert 1971) was conducted with the software PAST 2.02 Hammer \& Harper, Norway (Hammer et al. 2001). The abundance of the fragments was compared with the software PAST 2.02 through an ANOVA test, in which the total abundance values of each transect were used.

The species behavioral guild was attributed according to literature (Halffter and Edmonds 1982, Cambefort and Hanski 1991, Doube 1991, Gill 1991), being the species classified as tunnelers (take food from and carry it to galleries constructed beneath or next to the food source), rollers (rotate portions of food to bury them in distant galleries) or dwellers (remain in the food source, feeding themselves and nesting there).

The group of dominant species was qualified as the sum of their relative abundance reached a minimum of $70 \%$. The constancy of species along the period of collection was calculated using the formula presented by Silveira-Neto et al. (1976), being the species classified as: constant (those present in more than $50 \%$ of samples), accessory (present in 25$50 \%$ ) and accidental (present in less than 25\%).

The diversity of each habitat sampled was calculated through the indexes of Shannon-Wiener (H') and Margalef $\left(\mathrm{D}_{\mathrm{Mg}}\right)$ (Moreno 2001). The dominance indexes of Simpson (D) and BergerParker (d) were calculated in order to assess the level of dominance in the assemblies of Scarabaeinae (Magurran 1988, Moreno 2001). All these indexes were estimated through the software PAST 2.02.

In order to verify the qualitative similarity among the habitats, the coefficients of Jaccard $\left(\mathrm{I}_{\mathrm{J}}\right)$ and Sorensen $\left(\mathrm{I}_{\mathrm{S}}\right)$ were used. The index of Morisita-Horn $\left(\mathrm{I}_{\mathrm{MH}}\right)$ and the quantitative coefficient of Sorensen ( $\mathrm{I}_{\text {Squant }}$ ) were calculated to verify the quantitative similarity among the fragments (Moreno 2001). Based on the similarity values obtained, the beta diversity was calculated through qualitative and quantitative data, thus subtracting 1 (one) from the similarity value (Verdú et al. 2007).

The equitability was calculated with the Pielou index (J') (Magurran 1988). The data normality was assessed through the Shapiro-Wilk test with the software PAST 2.02 .

\section{Meteorological Data}

The data of air temperature (minimum, average and maximum), pluvial precipitation, relative humidity and insolation period between May 2009 and April 2010 were provided by the Meteorological Station at Universidade Federal de Santa Maria (Departamento de Fitotecnia), linked to the Instituto Nacional de Meteorologia (INMET). The INMET basis for data collection covers a radius of $20 \mathrm{~km}$ and the areas studied are within this range allowing the test of correlation to be realized.

The monthly number of species and individuals of Scarabaeinae was correlated with meteorological data through the coefficient of Pearson $\left(\mathrm{R}_{\mathrm{P}}\right)$ in order to find possible relationships 
between the abiotic variables and the temporal distribution of species. In order to homogenize the variance, the data were transformed on the square root of their initial values. A discussion about the number of individuals and species per month of collection and season is presented.

\section{RESULTS}

The collections resulted in a total of 19,699 individuals, belonging to six tribes, 13 genera and 33 species. Among the three habitats sampled, Canthidium aff. trinodosum Boheman, 1858 (24.9\%), Canthon latipes Blanchard, 1845 (1.4\%),

\section{TABLE I}

Species of Scarabaeinae (Coleoptera: Scarabaeidae) sampled using baited pitfall traps in three forest fragments in Santa Maria, Rio Grande do Sul, Brazil, between May 2009 and April 2010. MOEL: 'Morro do Elefante'; MOCE: 'Morro do Cerrito'; UFSM: 'Campus da Universidade Federal de Santa Maria'. (*) indicate species found only in one habitat. S: number of species; $N$ : number of individuals; \%: percentage of individuals in relation to the total captured; BG: behavioral guild; D: dweller; R: roller; T: tunneler; CO: constancy; A: constant; B: accessory; C: accidental. The number of each species is used to differentiate them in Figure 1.

\begin{tabular}{|c|c|c|c|c|c|c|c|}
\hline \multirow{2}{*}{ Tribe/species } & \multicolumn{3}{|c|}{ Habitats } & \multirow{2}{*}{ Total } & \multirow{2}{*}{$\%$} & \multirow{2}{*}{ BG } & \multirow{2}{*}{$\mathrm{CO}$} \\
\hline & MOEL & MOCE & UFSM & & & & \\
\hline \multicolumn{8}{|c|}{ Ateuchini $(\mathrm{S}=3 ; \mathrm{N}=195)$} \\
\hline 1. Ateuchus aff. carbonarius (Harold, 1868) * & 0 & 1 & 0 & 1 & 0.01 & $\mathrm{~T}$ & $\mathrm{C}$ \\
\hline 2. Ateuchus aff. robustus (Harold, 1868) & 13 & 24 & 31 & 68 & 0.35 & $\mathrm{~T}$ & $\mathrm{~B}$ \\
\hline 3. Uroxys aff. terminalis Waterhouse, 1891 & 19 & 100 & 7 & 126 & 0.64 & $\mathrm{~T}$ & A \\
\hline \multicolumn{8}{|c|}{ Coprini $(S=10 ; N=10,221)$} \\
\hline 4. Canthidium aff. dispar Harold, 1867 & 257 & 210 & 1 & 468 & 2.38 & $\mathrm{~T}$ & A \\
\hline 5. Canthidium moestum Harold, 1867 & 33 & 2 & 17 & 52 & 0.26 & $\mathrm{~T}$ & $\mathrm{~B}$ \\
\hline 6. Canthidium aff. trinodosum (Boheman, 1858) & 3,048 & 1,854 & 21 & 4,923 & 24.9 & $\mathrm{~T}$ & A \\
\hline 7. Canthidium sp. & 592 & 450 & 4 & 1,046 & 5.31 & $\mathrm{~T}$ & A \\
\hline 8. Dichotomius aff. acuticornis (Luederwaldt, 1930) & 9 & 17 & 0 & 26 & 0.13 & $\mathrm{~T}$ & $\mathrm{~B}$ \\
\hline 9. Dichotomius assifer (Eschscholtz, 1822) & 346 & 2,659 & 0 & 3,005 & 15.2 & $\mathrm{~T}$ & A \\
\hline 10. Dichotomius nisus (Olivier, 1789) & 4 & 2 & 22 & 28 & 0.14 & $\mathrm{~T}$ & $\mathrm{~B}$ \\
\hline 11. Homocopris sp. * & 2 & 0 & 0 & 2 & 0.01 & $\mathrm{~T}$ & $\mathrm{C}$ \\
\hline 12. Ontherus azteca Harold, 1869 & 15 & 22 & 6 & 43 & 0.22 & $\mathrm{~T}$ & $\mathrm{~B}$ \\
\hline 13. Ontherus sulcator (Fabricius, 1775) & 75 & 188 & 365 & 628 & 3.19 & $\mathrm{~T}$ & A \\
\hline \multicolumn{8}{|c|}{ Deltochilini $(S=11 ; N=6,216)$} \\
\hline 14. Canthon amabilis Balthasar, 1939 & 34 & 215 & 0 & 249 & 1.26 & $\mathrm{R}$ & $\mathrm{B}$ \\
\hline 15. Canthon chalybaeus Blanchard, 1845 & 27 & 7 & 399 & 433 & 2.2 & $\mathrm{R}$ & A \\
\hline 16. Canthon latipes Blanchard, 1845 & 739 & 2,492 & 0 & 3,231 & 16.4 & $\mathrm{R}$ & A \\
\hline 17. Canthon lividus Blanchard, 1845 & 563 & 118 & 5 & 686 & 3.48 & $\mathrm{R}$ & A \\
\hline 18. Canthon aff. luctuosus Harold, 1868 & 195 & 305 & 2 & 502 & 2.55 & $\mathrm{R}$ & A \\
\hline 19. Canthon oliverioi Pereira \& Martínez, 1956 & 58 & 22 & 0 & 80 & 0.41 & $\mathrm{R}$ & $\mathrm{B}$ \\
\hline 20. Canthon quinquemaculatus Castelnau, 1840 & 17 & 2 & 447 & 466 & 2.37 & $\mathrm{R}$ & A \\
\hline 21. Deltochilum brasiliense (Castelnau, 1840) & 16 & 8 & 0 & 24 & 0.12 & $\mathrm{R}$ & $\mathrm{B}$ \\
\hline 22. Deltochilum morbillosum Burmeister, 1848 & 26 & 5 & 0 & 31 & 0.16 & $\mathrm{R}$ & $\mathrm{B}$ \\
\hline 23. Deltochilum rubripenne (Gory, 1831) & 135 & 359 & 3 & 497 & 2.52 & $\mathrm{R}$ & A \\
\hline 24. Deltochilum sculpturatum Felsche, 1907 & 5 & 0 & 12 & 17 & 0.09 & $\mathrm{R}$ & $\mathrm{B}$ \\
\hline
\end{tabular}


TABLE I (CONTINUATION)

\begin{tabular}{|c|c|c|c|c|c|c|c|}
\hline \multirow{2}{*}{ Tribe/species } & \multicolumn{3}{|c|}{ Habitats } & \multirow{2}{*}{ Total } & \multirow{2}{*}{$\%$} & \multirow{2}{*}{ BG } & \multirow{2}{*}{$\mathrm{CO}$} \\
\hline & MOEL & MOCE & UFSM & & & & \\
\hline \multicolumn{8}{|c|}{ Phanaeini $(\mathrm{S}=4 ; \mathrm{N}=627)$} \\
\hline 25. Coprophanaeus milon (Blanchard, 1845) & 2 & 0 & 39 & 41 & 0.21 & $\mathrm{~T}$ & B \\
\hline 26. Coprophanaeus saphirinus (Sturm, 1826) & 277 & 280 & 0 & 557 & 2.83 & $\mathrm{~T}$ & A \\
\hline 27. Phanaeus splendidulus (Fabricius, 1781) & 14 & 11 & 0 & 25 & 0.13 & $\mathrm{~T}$ & $\mathrm{C}$ \\
\hline 28. Sulcophanaeus rhadamanthus (Harold, 1875) * & 4 & 0 & 0 & 4 & 0.02 & $\mathrm{~T}$ & $\mathrm{C}$ \\
\hline \multicolumn{8}{|c|}{ Oniticellini $(\mathrm{S}=3 ; \mathrm{N}=1,576)$} \\
\hline 29. Eurysternus aeneus Génier, 2009 * & 0 & 0 & 1 & 1 & 0.01 & $\mathrm{D}$ & $\mathrm{C}$ \\
\hline 30. Eurysternus caribaeus (Herbst, 1789) & 407 & 962 & 73 & 1,442 & 7.32 & $\mathrm{D}$ & A \\
\hline 31. Eurysternus parallelus Castelnau, 1840 & 47 & 83 & 3 & 133 & 0.68 & $\mathrm{D}$ & A \\
\hline \multicolumn{8}{|c|}{ Onthophagini $(\mathrm{S}=2 ; \mathrm{N}=864)$} \\
\hline 32. Onthophagus catharinensis Paulian, 1936 & 55 & 453 & 0 & 508 & 2.58 & $\mathrm{~T}$ & A \\
\hline 33. Onthophagus aff. tristis Harold, 1873 & 53 & 238 & 65 & 356 & 1.81 & $\mathrm{~T}$ & A \\
\hline Number of individuals & 7,087 & 11,089 & 1,523 & 19,699 & & & \\
\hline Number of species & 31 & 28 & 20 & 33 & & & \\
\hline
\end{tabular}

Dichotomius assifer (Eschscholtz 1822) (15.2\%), Eurysternus caribaeus (Herbst 1789) (7.3\%), Canthidium sp. (5.3\%) and Canthon lividus Blanchard, 1845 (3.4\%) were the most abundant

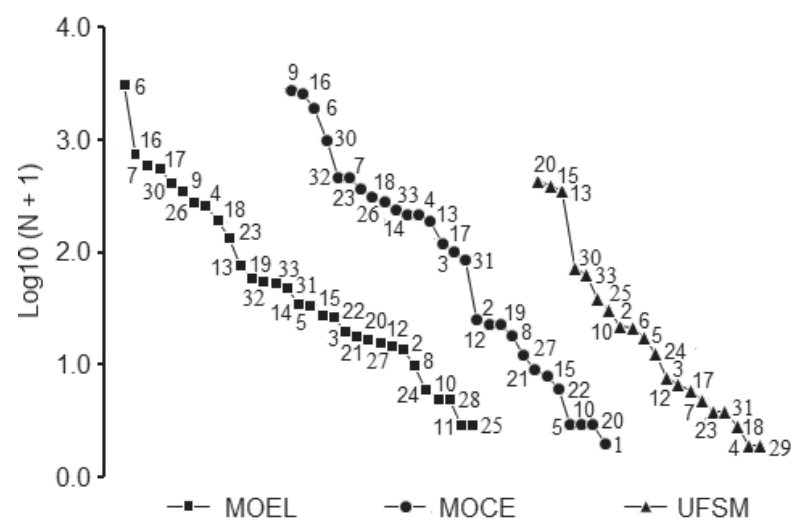

Figure 1 - Rank-abundance plots (N) of Scarabaeinae species (Coleoptera: Scarabaeidae) captured by pitfall traps baited with human excrement, rotten meat and rotten bananas in three forest fragments in Santa Maria, Rio Grande do Sul, Brazil, between May 2009 and April 2010. MOEL: 'Morro do Elefante'; MOCE: 'Morro do Cerrito'; UFSM: 'Campus da Universidade Federal de Santa Maria'. The relative abundance of each species was transformed into logarithm base 10 $(\mathrm{N}+1)$ and arranged from highest to lowest value for each habitat. The numbers are relative to species in Table I. species and together accounted for $72.7 \%$ of the total number of individuals captured (Table I).

The composition of dominant species among the investigated fragments was different (Figure 1). The five dominant species $(15.1 \%)$ in MOEL were $C$. aff. trinodosum (43\%), C. latipes (10.4\%), Canthidium sp. (8.3\%), C. lividus (7.9\%) and E. caribaeus (5.7\%), that together totaled $75.4 \%$ of the total number of individuals. In MOCE, the four species (14.2\%) that together represented $71.8 \%$ of the total were $D$. assifer (23.9\%), C. latipes (22.4\%), C. aff. trinodosum (16.7\%) and E. caribaeus (8.6\%). The fragment UFSM showed $79.5 \%$ of dominance of three species (15\%): Canthon quinquemaculatus (Castelnau 1840) (29.3\%), C. chalybaeus Blanchard, 1845 (26.2\%) and Ontherus sulcator (Fabricius 1775) (23.9\%).

All the sampling sufficiency curves reached an asymptote (Figure 2), demonstrating how successful was the capture of the species of Scarabaeinae attracted by the baits used in the three habitats sampled.

The number of species detected in each fragment was approximate to the expected, based 


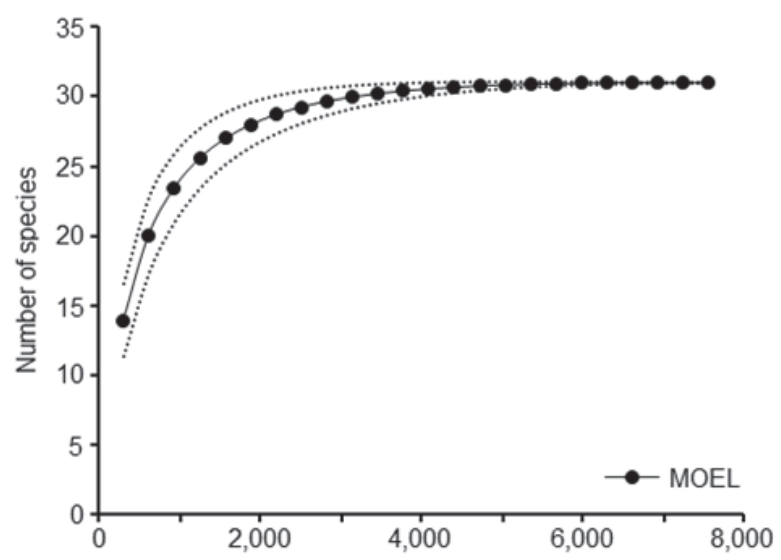

on the richness estimators (Chao 1 and 2, Jackknife 1 and 2, and Bootstrap) (Table II) and they indicated the efficiency in the sampling of the local richness. To MOEL, the minimum capture was approximately $98.6 \%$ of the estimated Scarabaeinae fauna. In MOCE it was $91.7 \%$, and in UFSM 97\%.

In order to standardize the abundance in 1,523 individuals for each fragment, the method of rarefaction was used and it was possible to evidence

\section{TABLE II}

Observed and estimated (with standard deviation) richness of Scarabaeinae (Coleoptera: Scarabaeidae) for the forest fragments sampled with baited pitfall traps in Santa Maria, Rio Grande do Sul, Brazil, between

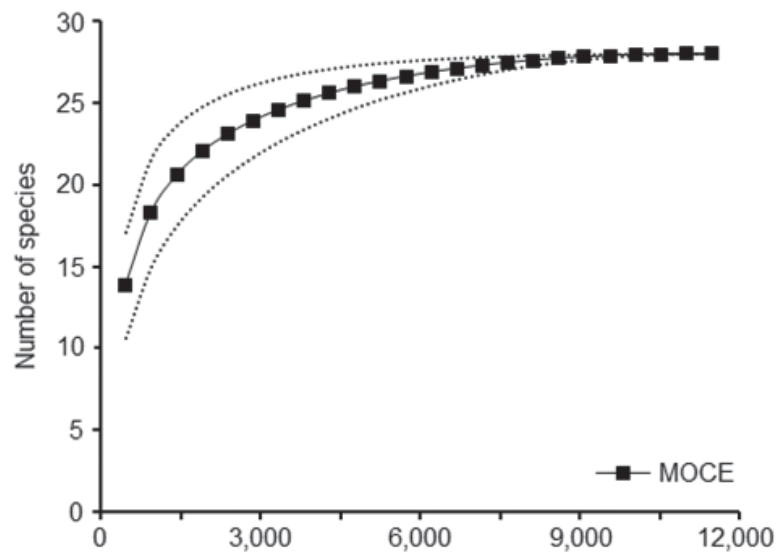

May 2009 and April 2010. MOEL: 'Morro do Elefante';

MOCE: 'Morro do Cerrito'; UFSM: 'Campus da Universidade Federal de Santa Maria'.

\begin{tabular}{lccc}
\hline \multirow{2}{*}{ Estimators } & \multicolumn{3}{c}{ Habitats } \\
\cline { 2 - 4 } & MOEL & MOCE & UFSM \\
\hline $\begin{array}{l}\text { Observed } \\
\text { richness }\end{array}$ & 31 & 28 & 20 \\
Bootstrap & $31.25 \pm 0.62$ & $28.29 \pm 1.74$ & $20.32 \pm 0.85$ \\
Chao 1 & $30.91 \pm 0.18$ & $27.59 \pm 0.36$ & $20.08 \pm 0.56$ \\
Chao 2 & $31.28 \pm 0.74$ & $30.51 \pm 2.79$ & $20.38 \pm 1.21$ \\
Jackknife 1 & $31.43 \pm 0.61$ & $29.99 \pm 1.49$ & $20.60 \pm 0.83$ \\
Jackknife 2 & $31.01 \pm 1.91$ & $28.91 \pm 4.95$ & $19.88 \pm 2.47$ \\
\hline
\end{tabular}

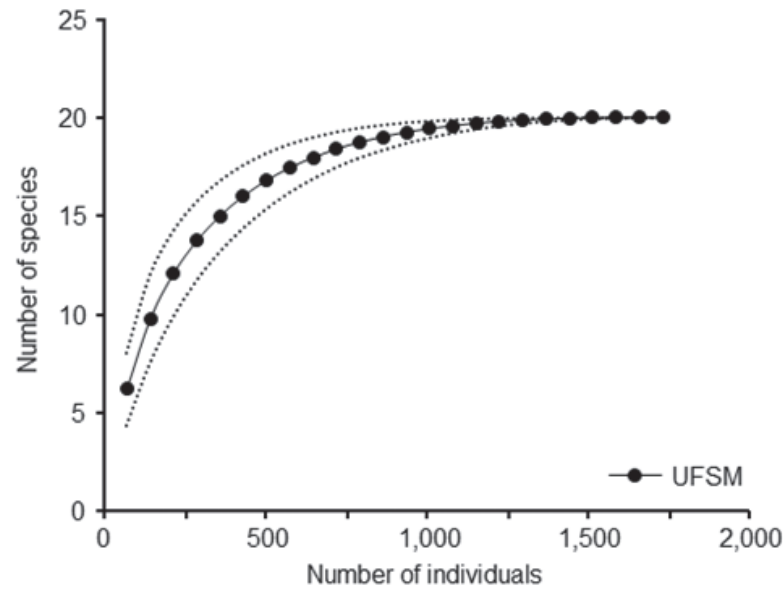

Figure 2 - Sample sufficiency curve (Mao Tau function) for three forest fragments sampled with baited pitfall traps in Santa Maria, Rio Grande do Sul, Brazil, between May 2009 and April 2010. MOEL: 'Morro do Elefante'; MOCE: 'Morro do Cerrito'; UFSM: 'Campus da Universidade Federal de Santa Maria'.

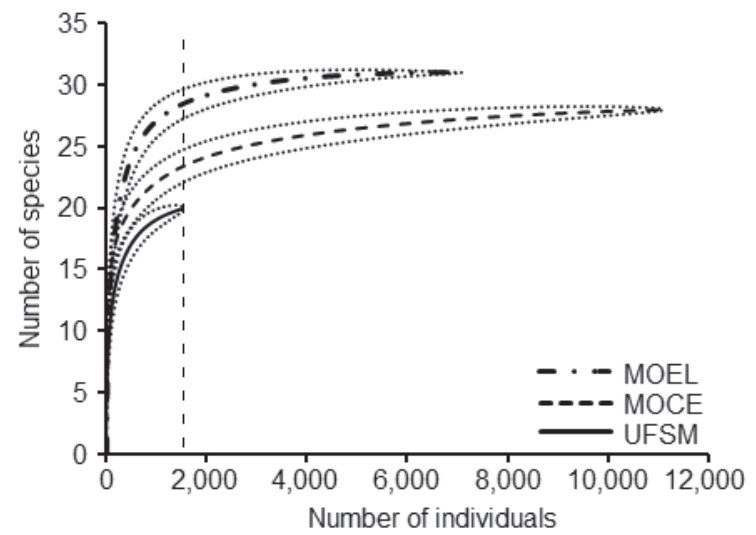

Figure 3 - Rarefaction curve with standard deviation for the assemblies of Scarabaeinae (Coleoptera: Scarabaeidae) captured using baited pitfall traps in three forest fragments in Santa Maria, Rio Grande do Sul, Brazil, between May 2009 and April 2010. MOEL: 'Morro do Elefante'; MOCE: 'Morro do Cerrito'; UFSM: 'Campus da Universidade Federal de Santa Maria'. 
that the assemblies of Scarabaeinae were similar to what had been previously observed, with greater richness in the largest and most preserved fragment MOEL ( $\mathrm{S}=28.4 \pm 1.18)$, intermediate richness in MOCE $(\mathrm{S}=23.3 \pm 1.30)$ and lowest richness in the smallest and most disturbed fragment (20) (Figure 3).

There was a significant statistical difference in the distribution of the abundance of Scarabaeinae in the fragments $(F=14.875$; d.f. $=2 ; p<0.01)$, where only MOEL and MOCE did not differ in number of individuals per transect, since these are larger and more preserved fragments than UFSM.

The greatest value of the dominance index of Berger-Parker occurred in MOEL (d: 0.430) (Table III), and expressed the greatest proportion of the most abundant species (C. aff. trinodosum - 43\%) in this fragment in relation to the total number of individuals, differently from what occurred in the other two habitats. The Simpson index also showed a higher value for MOEL (D: 0.219).

TABLE III

Measures' summary of richness, abundance, diversity, evenness and similarity of Scarabaeinae (Coleoptera: Scarabaeidae) in each forest fragment sampled in Santa Maria, Rio Grande do Sul, Brazil. MOEL: 'Morro do Elefante'; MOCE: 'Morro do Cerrito'; UFSM: 'Campus da Universidade Federal de Santa Maria'.

\begin{tabular}{|c|c|c|c|c|}
\hline \multirow{2}{*}{ Parameter evaluated } & \multicolumn{3}{|c|}{ Habitats } & \multirow{2}{*}{ Total } \\
\hline & MOEL & MOCE & UFSM & \\
\hline Total abundance & 7,087 & 11,089 & 1,523 & 19,699 \\
\hline Monthly mean abundance & 295,29 & 462,04 & 63,46 & 820,79 \\
\hline Abundance in pitfalls with meat & 2,094 & 193 & 705 & 3,992 \\
\hline Abundance in pitfalls with feces & 4,529 & 9,500 & 745 & 14,774 \\
\hline Abundance in pitfalls with bananas & 464 & 396 & 73 & 933 \\
\hline Total richness & 31 & 28 & 20 & 33 \\
\hline Estimated richness & 31.18 & 28.86 & 20.25 & 33.26 \\
\hline Monthly mean richness & 12.87 & 12.87 & 5.50 & 17.87 \\
\hline Richness in pitfalls with meat & 28 & 22 & 15 & 29 \\
\hline Richness in pitfalls with feces & 31 & 27 & 18 & 33 \\
\hline Richness in pitfalls with bananas & 21 & 19 & 10 & 25 \\
\hline Tunnelers & 18 & 16 & 11 & 19 \\
\hline Dwellers & 2 & 2 & 3 & 3 \\
\hline Rollers & 11 & 10 & 6 & 11 \\
\hline Singletons & 0 & 1 & 2 & 2 \\
\hline Doubletons & 2 & 3 & 1 & 1 \\
\hline Restricted species & 2 & 1 & 1 & - \\
\hline Shared species & 29 & 27 & 19 & - \\
\hline Pielou's evenness & 0.622 & 0.677 & 0.614 & 0.709 \\
\hline Margalef index & 3.384 & 2.899 & 2.593 & 3.236 \\
\hline Shannon-Wiener index & 2.135 & 2.257 & 1.839 & 2.479 \\
\hline Berger-Parker index (dominance) & 0.430 & 0.239 & 0.293 & 0.249 \\
\hline Simpson index (dominance) & 0.219 & 0.151 & 0.218 & 0.128 \\
\hline Jaccard mean qualitative similarity $^{1}$ & 0.719 & 0.696 & 0.571 & - \\
\hline Sorensen mean qualitative similarity ${ }^{1}$ & 0.830 & 0.812 & 0.727 & - \\
\hline Morisita-Horn mean quantitative similarity ${ }^{1}$ & 0.356 & 0.357 & 0.064 & - \\
\hline Sorensen mean quantitative similarity ${ }^{1}$ & 0.321 & 0.314 & 0.073 & - \\
\hline
\end{tabular}

\footnotetext{
${ }^{1}$ Mean between habitats.
} 
This index, strongly influenced by the set of the most abundant species (Magurran 1988), showed higher values for these fragments due to the greater proportion of dominant species, accounting for more than $75 \%$ of individuals in these habitats, the same not occurring in MOCE.

MOEL showed a lower equitability value than MOCE (Table III), though it clearly presented more richness and smaller number of individuals. The influence of the greatest number of species represented by few individuals present in MOEL may have contributed to these results, and also to the values of dominance found in this fragment.

In total, 17 species (51.5\%) were classified as constants, from which four showed constancy above $90 \%$, five between $75-90 \%$ and eight between $50-75 \%$. Eleven species (33.4\%) were classified as accessory, being five (15.1\%) accidental, three of which classified as uniques (occurred in one sample only) and one duplicate (occurred in two samples only). In MOEL, 11 species $(35.5 \%)$ were constants, and only one showed higher constancy than $90 \%$ (C) aff. trinodosum). Twelve species (38.7\%) were accessory and eight (25.8\%) accidental (one unique and two duplicates). In MOCE, 14 species (50\%) were classified as constants, two of which showed constancy above $90 \%$ (C. aff. trinodosum and $D$. assifer). Five species (17.8\%) were accessory, while nine (32.2\%) were accidental (five uniques and one duplicate). In UFSM, only four species (20\%) were constants, and no one showed more than $75 \%$ of constancy. Five species $(25 \%)$ were accessory and eleven (55\%) were classified as accidental (two uniques and three duplicates). Considering the three habitats, 19 species $(57.5 \%)$ were tunnelers, $11(33.4 \%)$ rollers and only three (9.1\%) were dwellers.

The species restricted to only one fragment were Homocopris sp. (doubleton) and Sulcophanaeus rhadamanthus (Harold 1875), which occurred only in MOEL; Ateuchus aff. carbonarius (Harold
1868) (singleton) was evidenced only in MOCE; and Eurysternus aeneus Génier, 2009 (singleton) occurred only in UFSM.

The data concerning observed and rarefied richness indicated higher alpha diversity (31 species) for the largest and most preserved area (MOEL) in relation to the other two fragments. MOCE held the highest value for the diversity index of ShannonWiener (2.257), influenced by the greatest equitability (0.681) showed in this fragment. However, no significant difference was found between MOCE and MOEL. The Margalef index was the highest for MOEL (3.384), since it showed the highest richness with less total abundance than MOCE, there being significant difference among all three fragments.

The qualitative similarity for the three fragments calculated through the coefficients of Jaccard and Sorensen showed higher values between MOEL and MOCE (Table IV), since the number of species shared between the two habitats (27) was elevated. When paired with UFSM the two fragments showed similarity lower than $60 \%$ according to Jaccard, and lower than $75 \%$ according to Sorensen, a result which was strongly influenced by the difference in the richness of each fragment. The quantitative similarity expressed by the indexes of Morisita-Horn and Sorensen (quantitative) was also higher for areas with the highest percentage of natural forest vegetation (MOEL and MOCE) and, when paired with UFSM, they showed very low similarity indexes due to the great differences in richness, abundance and species dominance among the pairs of fragments.

The qualitative beta diversity, or the degree of rearrangement of species, was more evident between MOCE and UFSM due to the smaller number of shared species (17) between these fragments. When using quantitative data, the degree of difference becomes $93.7 \%$ between the most preserved and the most disturbed habitats.

The greatest abundance of Scarabaeinae between the months of collections was found in October (4,759 individuals - 24.2\%), November 
TABLE IV

Qualitative and quantitative similarity values of Scarabaeinae (Coleoptera: Scarabaeidae) fauna between pair of forest fragments sampled in Santa Maria, Rio Grande do Sul, Brazil, between May 2009 and April 2010. In parenthesis, beside the values of similarity is given the values of beta diversity calculated by deducting the value of similarity of 1 (one) (Verdú et al. 2007). MOEL: 'Morro do Elefante'; MOCE: 'Morro do Cerrito'; UFSM: 'Campus da Universidade Federal de Santa Maria'.

\begin{tabular}{lccc}
\hline \multirow{2}{*}{ Indexes } & \multicolumn{3}{c}{ Pairs of forest fragments } \\
\cline { 2 - 4 } & MOEL x MOCE & MOEL x UFSM & MOCE x UFSM \\
\hline Jaccard $\left(\mathrm{I}_{\mathrm{J}}\right)$ & $0.844(0.156)$ & $0.594(0.406)$ & $0.548(0.452)$ \\
Sorensen - qualitative $\left(\mathrm{I}_{\mathrm{S}}\right)$ & $0.915(0.085)$ & $0.745(0.255)$ & $0.708(0.292)$ \\
Morisita - Horn $\left(\mathrm{I}_{\mathrm{MH}}\right)$ & $0.649(0.351)$ & $0.063(0.937)$ & $0.065(0.935)$ \\
Sorensen - quantitative $\left(\mathrm{I}_{\text {Squant }}\right)$ & $0.562(0.438)$ & $0.079(0.921)$ & $0.066(0.934)$ \\
\hline
\end{tabular}

(4,162 individuals - 21.1\%) and December (3,336 individuals $-16.9 \%$ ), representing $62.2 \%$ of the total individuals captured (Figure $4 \mathrm{a}$ ). The other months remained under 2,000 individuals per collection. July 2009 was the month with the lowest abundance (118 individuals $-0.6 \%$ ).

The greatest richness also coincided with the period of greatest abundance (October: 30 species; November: 29 species; December and
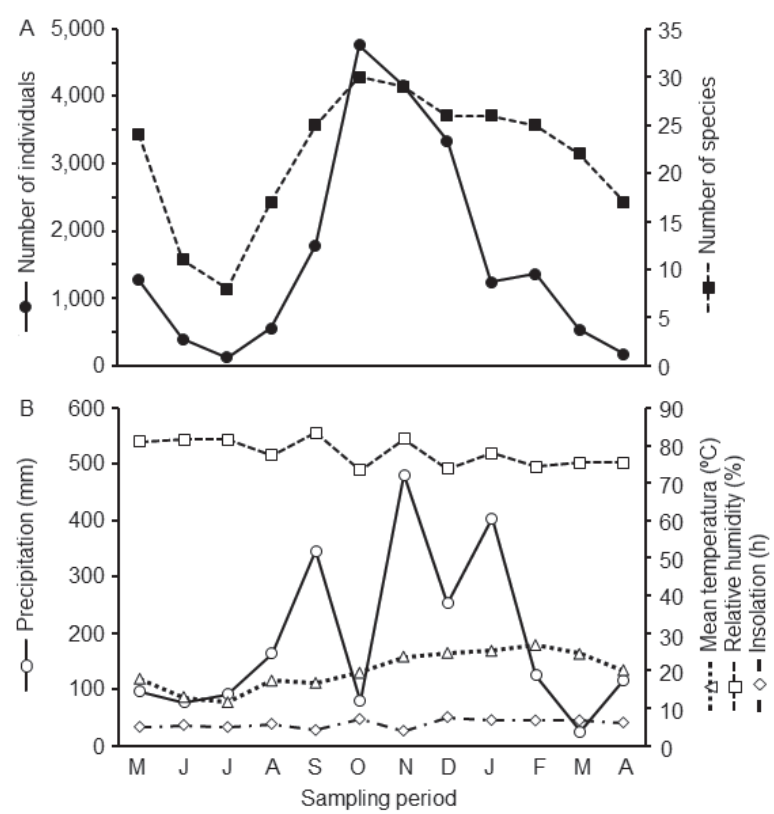

Figure 4 - Number of individuals and species of Scarabaeinae (Coleoptera: Scarabaeidae) collected per month in Santa Maria, Rio Grande do Sul, Brazil, between May 2009 and April 2010 (A) and distribution of environmental variables during the study period (B).
January: 26 species each), as well as the smallest richness captured (July: eight species). The Pearson correlation test found a positive relation between richness and abundance variables $\left(\mathrm{R}_{\mathrm{P}}=0.83 ; \mathrm{p}<\right.$ 0.0001). For each fragment, November was the month with the greatest abundance and richness for MOEL $(\mathrm{N}=1,487 ; \mathrm{S}=28)$ and UFSM $(\mathrm{N}=$ 571; $\mathrm{S}=14$ ), while October with the highest values for MOCE in terms of species (26) and individuals $(3,154)$. In general terms, July and June respectively were the months of lowest richness and abundance among the fragments, coinciding with the period of the lowest temperatures in the region.

Among the seasons, spring was the one with the greatest abundance and richness $(11,923$ individuals

\section{TABLE V}

Pearson' linear correlation between environmental variables and abundance and richness of Scarabaeinae (Coleoptera: Scarabaeidae) collected using baited pitfall traps in three forest fragments in Santa Maria, Rio

Grande do Sul, Brazil, between May 2009 and April 2010. Asterisks indicate statistical significance at level of $0.05(*)$ and $0.01(* *)$ probability.

\begin{tabular}{ccc}
\hline Environmental variables & Abundance & Richness \\
\hline Relative humidity $(\%)$ & -0.26 & -0.38 \\
Minimum temperature $\left({ }^{\circ} \mathrm{C}\right)$ & $0.44 *$ & $0.72 * *$ \\
Mean temperature $\left({ }^{\circ} \mathrm{C}\right)$ & $0.43^{*}$ & $0.72 * *$ \\
Maximum temperature $\left({ }^{\circ} \mathrm{C}\right)$ & $0.41^{*}$ & $0.70^{* *}$ \\
Precipitation $(\mathrm{mm})$ & 0.31 & 0.29 \\
Insolation $(\mathrm{h})$ & 0.13 & 0.26 \\
\hline
\end{tabular}


- 31 species), followed by summer (4,010 individuals - 29 species). Autumn had the lowest abundance $(1,798)$, and winter the smallest richness (24). Similar patterns were found for each area, in which spring had the greatest abundance, followed by summer. In relation to richness, spring presented the highest number of species collected, followed by summer, except for the most disturbed area (UFSM), where the second highest number of species (richness) was found in autumn and not in summer.

Among the climatic variables evaluated (Figure 4b), air temperature was the only variable positively correlated with abundance and richness of Scarabaeinae during the period of collection (Table V).

\section{DISCUSSION}

The richness of Scarabaeinae (33) does not differ much from that found in other studies which made use of baited pitfall traps in forest fragments in South and Southeastern Brazil (Lopes et al. 1994, Louzada and Lopes 1997, Medri and Lopes 2001, Almeida and Louzada 2009, Hernández and Vaz-de-Mello 2009). According to the curves of sample sufficiency and the richness estimators, the capture of the Scarabaeinae in the sampled fragments was satisfactory.

The number of dominant species increased according to the size and the decrease in the level of fragment's alteration. According to Halffter (1991), Scarabaeinae is represented by a few abundant species and many species with few individuals in Neotropical forests. This pattern has been often found in studies conducted in forest ecosystems (e.g., Louzada and Lopes 1997, Vazde-Mello 1999, Medri and Lopes 2001, Milhomem et al. 2003, Endres et al. 2007, Louzada et al. 2007, Filgueiras et al. 2009, Hernández and Vaz-de-Mello 2009, Audino et al. 2011, Lopes et al. 2011, Silva 2011), in areas of fields or pastures in Brazil (e.g., Koller et al. 2007, Matavelli and Louzada 2008,
Louzada and Silva 2009, Silva et al. 2009, Lopes et al. 2011, Silva 2011), as well as other Neotropical countries such as Bolivia (Spector and Ayzama 2003), Colombia (Martínez et al. 2009), Ecuador (Peck and Forsyth 1982), Mexico (Halffter et al. 1992) and Uruguay (Morelli et al. 2002).

By using the method of rarefaction it was possible to observe that the assemblies of Scarabaeinae appeared in a similar manner to what had been observed. The characteristics of the interior and the surroundings of the fragments appear to have contributed to the results. Another important factor is the availability of food (Halffter and Matthews 1966), since mammals are more likely to settle and remain in larger and more preserved ecosystems. Thus, they contribute to the increase in the availability of dung and carcasses for the fauna of Scarabaeinae. It is likely that environments closer to natural might harbor species of fruit trees, provide a greater supply of food resources to generalist species of Scarabaeinae.

A greater number of tunnellers in relation to other behavioral guilds was found. This pattern in which there is a larger number of tunnellers is common in Neotropical forests (Halffter et al. 1992, Louzada and Lopes 1997) and was also detected in each of the fragments sampled. Apparently, the constant proportional distribution in behavioral guilds seems to be the result of local diversity of tribes of Scarabaeinae in Neotropical forests (Louzada and Lopes 1997). On the other hand, the proportion of tribes, genera and species captured with baits is restricted to a greater part of the Scarabaeinae fauna, since several groups of species are generally not attracted by baited traps (see Vazde-Mello et al. 1998, Vaz-de-Mello 2007, Vazde-Mello and Génier 2009). Thus, the interaction among the diversity of groups in the neotropics and the use of baits compatible with the feeding habits of most species seems to reflect the pattern found.

Even though represented by few individuals, the species restricted to only one fragment are 
important for understanding the differences found in them. Homocopris sp. and S. rhadamanthus were restricted to MOEL, Ateuchus aff. carbonarius was registered only in MOCE, and E. aeneus occurred only in UFSM. In Brazil, Homocopris Burmeister, 1846 , contains species restricted to the remnants of the Atlantic Forest, located throughout southeast and south of the country, currently under review where the species captured is being described (Vazde-Mello et al. 2010). Sulcophanaeus Olsoufieff, 1924 was reviewed by Edmonds (2000) and Arnaud (2002), comprising coprophagous or copro-necrophagous species and some, such as S. rhadamanthus, a rare species of Scarabaeinae with an unknown biology, but apparently related to fungi or mammal's burrows (Edmonds 2000). Eurysternus Dalman, 1824 was reviewed by Génier (2009), which stated that E. aeneus occurs in forested areas across southern Brazil, southern Paraguay and northeast Argentina. Its occurrence in exotic forest ecosystems is also known (authors' personal observation).

The influence of the high level of alteration, the isolation, the 'rural' surroundings and the smallest size may greatly contribute to the elevated rate of beta diversity among the most disturbed fragment and the ones which show more well preserved natural forest vegetation. Halffter and Arellano (2002) assume that differences among habitats found in their study (Veracruz, Mexico) and also in other locations brought into discussion, are due to vegetation cover and landscape heterogeneity, not solely because of food availability. The landscape heterogeneity can contribute to the survival of species that occur only in forested or in open areas (Halffter and Arellano 2002). In this sense, the reduction in area of forested fragments, by the expansion of pastures and/or agricultural areas, or even their transformation into forest cultures, can affect the survival of species that occur in forests and promote the expansion of species that prefer or adapt better in open areas (Halffter and Arellano
2002). Some Neotropical species of Scarabaeinae show high habitat specificity (Halffter 1991), especially for forest ecosystems, and thus, cannot extend their populations to open areas (Klein 1989, Spector and Ayzama 2003, Almeida and Louzada 2009). Such species are strongly influenced by habitat loss and fragmentation, which may have their distribution restricted or even disappear locally (Davis and Philips 2005).

The occurrence of species common to MOEL and UFSM may better illustrate the previously described situation, because the influence of open areas in these fragments is much higher than in MOCE. The similarity in species composition between MOEL and MOCE may be the result of previous processes being the latter apparently linked to the large set of hills with Deciduous Forest vegetation that occurs in the north side of Santa Maria, and that has become increasingly isolated along the years due to human expansion around this location. The fragment of UFSM, being situated on a flat terrain may have suffered a previous process of occupation, where the forest vegetation constituted primarily by gallery forest expanded along water courses, was removed and gave way to fields, pastures and crops. Thus, the current Scarabaeinae fauna remaining in the fragment seems to be mostly species originally occurring in open areas, and the size of this fragment, partly transformed into monocultures, is not sufficient to harbor most of the typically forest species.

Therefore, conservationist measures should consider as both forest and grassland are important ecosystems for the communities of Scarabaeinae, because both are complementary and may show a particularly unique diversity that increases the diversity of the landscape (Almeida and Louzada 2009). Although environments such as monocultures of exotic trees, very common in Brazil, may contribute to the beta diversity, they are not an ecosystem suitable for the maintenance of Scarabaeinae (Gardner et al. 2008). 
Differently from what occurs in tropical forests where rainfall affects the seasonality of the Scarabaeinae fauna (Halffter and Matthews 1966, Andresen 2008), the temperature is apparently the main cause for the seasonality of Scarabaeinae in subtropical forests and even other types of ecosystems in the subtropical regions. Halffter and Matthews (1966) stated that in temperate regions, adult specimens of Scarabaeinae usually nest in late spring and early summer. Then, as soon as new adults hatch (in the middle or late summer), they go through a hibernation period, which ends at the beginning of the following spring, spending the winter in their nests in the soil (Halffter and Matthews 1966). Thus, the expressive richness and abundance of Scarabaeinae found here in spring and summer follow the pattern described above. However, there was capture along the entire period of study, even though in winter and autumn the numbers were very low. Normally, the collected species were those that showed high abundance and were among the dominants of each fragment. Due to the large number of individuals, it is likely that these species reproduce and nest in late summer and early autumn, and emerge in shorts periods of mild temperatures during winter, once microclimatic effects within the fragment can contribute to this fact (Hernández and Vaz-de-Mello 2009). In general, the most uncommon species are more easily captured in the period of elevated temperatures, while the most abundant species occur throughout the year (Louzada and Lopes 1997).

The relationship between greater abundance and greater richness for periods of high temperatures is well known, especially for temperate regions, where the insect species show a decrease in activity in low temperatures and increase in periods of higher temperatures (Wolda 1988, Begon et al. 2007). Morelli et al. (2002) confirmed this pattern to the assemblies of Scarabaeinae in Uruguayan prairies, where the average temperature of air and soil was determinant for the species abundance and richness. Louzada and Lopes (1997) also reported a greater number of Scarabaeinae species during summer in Semi-Deciduous Secondary forest in Viçosa, Minas Gerais, Brazil, possibly influenced by temperature and precipitation.

Hernández and Vaz-de-Mello (2009) found a relationship between Scarabaeinae abundance and richness and warm and rainy period in Mesophytic Semi-Deciduous forest in São Paulo, Brazil, establishing a strong correlation between the number of species and the average temperature. These authors also observed a relationship between temperature and precipitation, both of which likely to influence the distribution of Scarabaeinae in that location. Hernández (2007) found a correlation between the number of species and individuals of Scarabaeinae and the rates of precipitation in Paraíba, Brazil. However, the climate in this region is semi-arid, the temperature undergoes little variation throughout the year, and the rainy season is the main factor that influences the dynamics of Scarabaeinae in these regions (Andresen 2008). For Scarabaeidae (sensu lato) attracted by light traps in Santa Maria, RS, D. Link (unpublished data) found a positive correlation between the distribution of this fauna and variables of nebulosity and insolation; and a negative correlation between evaporation and wind speed. While studying the Scarabaeoidea fauna of this region, this author concluded that Scarabaeidae (sensu lato) has no activity in temperatures below $7^{\circ} \mathrm{C}$, and above $37.4^{\circ} \mathrm{C}$ there is generally no activity of Scarabaeoidea.

Thus, due to the climatic conditions the region features, the temperature seems to be the main or most evident climatic factor that affects the activity of Scarabaeinae in subtropical climates, although its relationship with other factors not assessed here could influence the dynamics of this fauna (Halffter and Matthews 1966, D. Link, unpublished data). Very low temperatures, such as the ones occurring in the region in certain periods of the year, tend to cause death or hibernation of the specimens, which may, in most cases, go through this period of unfavorable climate in larval form (Halffter and Matthews 1966). 
Microclimatic factors, structure of the area and the soil, inter and intraspecific competition may also affect the structure, composition, diversity and abundance of Scarabaeinae in different ecosystems (Halffter and Matthews 1966, Davis et al. 1999, Halffter and Arellano 2002, Escobar et al. 2007, Nichols et al. 2007, Gardner et al. 2008), and they need further assessment.

The great richness evidenced in Santa Maria, including rare species of Scarabaeinae, adds important data to the fauna records of the central region of Rio Grande do Sul. Studies with various groups of animals, such as butterflies (Link et al. 1977, Schwartz and Di Mare 2001, Dessuy and Morais 2007, Sackis and Morais 2008), crustaceans (Bond-Buckup and Buckup 1994, Santos 2002), reptiles (Santos et al. 2005), anurans (Santos et al. 2008a), birds (Cechin et al. 2009), and mammals (Cáceres et al. 2007, Santos et al. 2008b), have shown great richness and the ecological importance of the region for the maintenance of species occurring in it (Cechin et al. 2009). Therefore, future policy actions will also have information on Scarabaeinae in relation to selecting priority areas for preservation in the region, where human activity increasingly threatens the maintenance of natural ecosystems. This region, characterized by the encounter of two biomes is a priority in terms of wildlife preservation, as it may be a site of species evolution, where evolutionary processes such as speciation and coevolution can be preserved (Spector 2002).

\section{ACKNOWLEDGMENTS}

We would like to thank the owners of the private properties sampled for allowing the study, Franciéle Garcês for assistance during fieldwork, Suzane Saldanha for improving the English version of the manuscript, Instituto Brasileiro do Meio Ambiente e dos Recursos Naturais Renováveis (IBAMA) for granting the license for the collections, Coordenação de Aperfeiçoamento de Pessoal de Nível Superior (CAPES) for providing the first author with the scholarship. This work has been partially supported by FAPEMAT (570847/2008 and 447441/2009) and CNPq (151603/2007-3 and 304925/2010-1).

\section{RESUMO}

Espécimes de Scarabaeinae foram coletados com o uso de armadilhas de queda iscadas com excremento humano, carne apodrecida e banana em decomposição, entre maio de 2009 e abril de 2010, em três fragmentos florestais em Santa Maria, Rio Grande do Sul, Brasil: Morro do Elefante (MOEL), Morro do Cerrito (MOCE) e Campus da Universidade Federal de Santa Maria (UFSM). Um total de 19.699 indivíduos de 33 espécies foi coletado; Canthidium aff. trinodosum Boheman, 1858, Canthon latipes Blanchard, 1845, Dichotomius assifer (Eschscholtz 1822), Eurysternus caribaeus (Herbst 1789), Canthidium sp. e Canthon lividus Blanchard, 1845 foram as espécies mais abundantes. MOEL apresentou a maior riqueza, MOCE a maior abundância, enquanto UFSM teve os menores valores de riqueza e abundância. A maior similaridade (qualitativa e quantitativa) ocorreu entre MOEL e MOCE, enquanto a menor ocorreu entre MOCE e UFSM. Apenas 51\% das espécies foram comuns aos três fragmentos. A riqueza e a abundância de Scarabaeinae estiveram positivamente correlacionadas com a temperatura do ar. A riqueza dos fragmentos diminuiu conforme o menor tamanho e maior grau de perturbação da estrutura da vegetação.

Palavras-chave: Mata Atlântica, rola-bosta, sul do Brasil, riqueza de espécies, distribuição temporal.

\section{REFERENCES}

ALMEIDA SSP AND LOUZADA JNC. 2009. Estrutura da comunidade de Scarabaeinae (Scarabaeidae: Coleoptera) em fitofisionomias do Cerrado e sua importância para a conservação. Neotrop Entomol 38: 32-43.

ANDRESEN E. 2003. Effect of forest fragmentation on dung beetle communities and functional consequences for plant regeneration. Ecography 26: 87-97.

ANDRESEN E. 2008. Short-term temporal variability in the abundance of tropical dung beetles. Ins Conserv Divers 1: $120-124$.

Arnaud P. 2002. Les Coléoptères du Monde, Phanaeini, vol. 28. Canterbury: Hillside Books, England, 151 p. 
Audino LD, NOGUEIRA JM, SILVA PG, NESKE MZ, RAMOS AHB, MoraEs LP AND BORBA MFS. 2007. Identificação dos coleópteros (Insecta: Coleoptera) das regiões de Palmas (município de Bagé) e Santa Barbinha (município de Caçapava do Sul), RS. Bagé: Embrapa Pecuária Sul, Brasil, $92 \mathrm{p}$.

Audino LD, Silva PG, Nogueira JM, Moraes LP AND VaZDE-MELLO FZ. 2011. Scarabaeinae (Coleoptera, Scarabaeidae) de um bosque de eucalipto introduzido em uma região originalmente campestre. Iheringia Sér Zool 101: 121-126.

AUSDEN M. 1996. Invertebrates. In: SUTHERLAND WJ (Ed), Ecological census techniques: a handbook, Great Britain: The Bath Press Avon, UK, p. 139-177.

BEGON M, TOWNSEND CR AND HARPER JL. 2007. Ecologia: de indivíduos a ecossistemas, $4^{\text {th }}$ ed., Porto Alegre: Artmed, Brasil, 752 p.

BENCKE GA. 2009. Diversidade e conservação da fauna dos campos do sul do Brasil. In: PILLAR VP ET AL. (Eds), Campos Sulinos - conservação e uso sustentável da biodiversidade, Brasília: Ministério do Meio Ambiente, Brasil, p. 101-121.

BILENCA DN AND MiÑARro F. 2004. Identificación de Áreas Valiosas de Pastizal (AVPs) en las Pampas y Campos de Argentina, Uruguay y sur de Brasil. Buenos Aires: Fundación de la Vida Silvestre, Argentina, 352 p.

Bond-Buckup G AND Buckup L. 1994. A família Aeglidae (Crustacea, Decapoda, Anomura). Arq Zool 32: 159-347.

BORNEMISSZA GF. 1976. The Australian dung beetle project, 1965-1975. Aust Meat Res Comm Rev 30: 1-30.

BROWN-Jr KS. 1991. Conservation of Neotropical environments: insects as indicators. In: Collins NM and Thomas JA (Eds), The conservation of insects and their habitats: $15^{\text {th }}$ Symposium of the Royal Entomological Society of London, London: Academic Press, UK, p. 349-404.

BROWN-Jr KS. 1997. Diversity, disturbance, and sustainable use of Neotropical forests: insects as indicators for conservation monitoring. J Ins Conserv 1: 25-42.

BROWN-Jr KS AND FREITAS AVL. 2000. Atlantic Forest butterflies: indicators for landscape conservation. Biotropica 32: 934-956.

CÁCERES NC, ChEREM JJ AND GRAIPEL ME. 2007. Distribuição geográfica de mamíferos terrestres na Região Sul do Brasil. Ciência \& Ambiente 35: 167-180.

CAMBEFORT Y AND HANSKI I. 1991. Dung beetle population biology. In: HANSKI I AND CAMBEFORT Y (Eds), Dung beetle ecology, Princeton: Princeton University Press, USA, p. 36-50.

Cechin SZ, Morais ABB, CÁceres NC, Santos S, Kotzian CB, BeHr ER, ARruda JS ANd Della-Flora F. 2009. Fauna de Santa Maria. Ciência \& Ambiente 38: 113-144.

COLWELL RK. 2004. EstimateS: Statistic estimation of species richness and shared species from samples. Version 7.0. Available at: http://viceroy.eeb.uconn.edu/EstimateS. Accessed on 15 November 2004.
CORDEIRO JLP AND HASENACK H. 2009. Cobertura vegetal atual do Rio Grande do Sul. In: PILLAR VP ET AL. (Eds), Campos Sulinos - conservação e uso sustentável da biodiversidade, Brasília: Ministério do Meio Ambiente, Brasil, p. 285-299.

Costa LP, Leite YLR, FonsecA GAB AND FonsecA MT. 2000. Biogeography of South American Forest Mammals: Endemism and Diversity in the Atlantic Forest. Biotropica 32: $872-881$.

Costa LP, Leite YLR, Mendes SL And Ditchfield AD 2005. Conservação de mamíferos no Brasil. Megadiversidade 1: 103-112.

Dambros VS, EISINGER SM AND CANTO-Dorow TS. 2004. Leguminosae do Campus da Universidade Federal de Santa Maria, Rio Grande do Sul, Brasil. Ciência e Natura 26: 43-60.

Davis AJ, Holloway JD, HuiJBregts H, KrikKen J, KirKSPRIGGS AH AND SUTTON SL. 2001. Dung beetles as indicators of change in the forests of northern Borneo. J Appl Ecol 38: 593-616.

DAVIS AL, SCHOLtz CH, DoOley P, BHAM N AND KRYGeR U. 2004. Scarabaeine dung beetles as indicators of biodiversity, habitat transformation and pest control chemicals in agro-ecosystems. S Afr J Sci 100: 415-424.

DAVIS ALV. 1996. Habitat associations in a South African, summer rainfall, dung beetle community (Coleoptera: Scarabaeidae, Aphodiidae, Staphylinidae, Histeridae, Hydrophilidae). Pedobiologia 40: 260-280.

DAVIS ALV AND PHILIPS TK. 2005. Effect of deforestation on a Southwest Ghana dung beetle assemblage (Coleoptera: Scarabaeidae) at the periphery of Ankasa conservation area. Environ Entomol 34: 1081-1088.

Davis ALV, Scholtz CH AND ChOWn SL. 1999. Species turnover, community boundaries and biogeographical composition of dung beetle assemblages across an altitudinal gradient in South Africa. J Biogeogr 26: 1039-1055.

DessuY MB AND Morais ABB. 2007. Diversidade de borboletas (Lepidoptera, Papilionoidea e Hesperioidea) em fragmentos de Floresta Estacional Decidual em Santa Maria, Rio Grande do Sul, Brasil. Rev Bras Zool 24: 108-120.

Doube BM. 1991. Dung beetle of Southern Africa. In: HANSKI I AND CAMBEFORT Y (Eds), Dung beetle ecology, Princeton: Princeton University Press, USA, p. 133-155.

EDMONDS WD. 2000. Revision of the Neotropical dung beetle genus Sulcophanaeus (Coleoptera: Scarabaeidae: Scarabaeinae). Folia Heyrov Suppl 6: 1-60.

ENDRES AA, CREÃo-DuARTE AJ AND HERNÁNDEZ MIM. 2007. Diversidade de Scarabaeidae s. str. (Coleoptera) da Reserva Biológica Guaribas, Mamanguape, Paraíba, Brasil: uma comparação entre Mata Atlântica e Tabuleiro Nordestino. Rev Bras Entomol 51: 67-71.

Escobar F, HalfFter G ANd ARELLANo L. 2007. From forest to pasture: an evaluation of the influence of environment and biogeography on the structure of dung beetle (Scarabaeinae) assemblages along three altitudinal gradients in the Neotropical region. Ecography 30: 193-208. 
FAVILA M AND HALFFTER G. 1997. The use of indicator groups for measuring biodiversity as related to community structure and function. Acta Zool Mex 72: 1-25.

FEARNSIDE PM. 2005. Desmatamento na Amazônia brasileira: história, índices e conseqüências. Megadiversidade 1: 113-123.

Filgueiras BKC, LIBERAL CN, AgUiar CDM, HeRnÁNDEZ MIM AND IANNUZZI L. 2009. Attractivity of omnivore, carnivore and herbivore mammalian dung to Scarabaeinae (Coleoptera, Scarabaeidae) in a tropical Atlantic Forest remnant. Rev Bras Entomol 53: 422-427.

FLECHTMANN CAH AND RODRIGUES SR. 1995. Insetos fimícolas associados a fezes bovinas em Jaraguá do Sul/ SC. 1. Besouros coprófagos (Coleoptera: Scarabaeidae). Rev Bras Entomol 39: 303-309.

GARdNer TA, Hernández MIM, BARlow B AND PEREs CA. 2008. Understanding the biodiversity consequences of habitat change: the value of secondary and plantation forests for Neotropical dung beetles. J Appl Ecol 45: 883-893.

GÉNIER F. 2009. Le genre Eurysternus Dalman, 1824 (Scarabaeidae: Scarabaeinae: Oniticellini), revision taxonomique et clés de determination illustrées. Sofia: Pensoft, Bulgary, $430 \mathrm{p}$.

GILL BD. 1991. Dung beetles in tropical American forests. In: HANSKI I AND CAMBEFORT Y (Eds), Dung beetle ecology, Princeton, Princeton University Press, USA, p. 211-229.

GIULIETTI AM, HARLEY RM, QUEIROZ LP, WANDERLEY MGL AND VAN-DEN-BERG C. 2005. Biodiversidade e conservação das plantas no Brasil. Megadiversidade 1: 52-61.

HALFFTER G. 1991. Historical and ecological factors determining the geographical distribution of beetles (Coleoptera: Scarabaeidae: Scarabaeinae). Folia Entomol Mex 82: 195-238.

HALfFter G. 2005. Towards a culture of biodiversity conservation. Acta Zool Mex 21: 133-153.

Halffter G AND Arellano L. 2002. Response of dung beetles diversity to human-induced changes in a tropical landscape. Biotropica 34: 144-154.

HALFFTER G AND EDMONDS WD. 1982. The nesting behavior of dung beetles (Scarabaeinae): An ecologic and evolutive approach. Mexico D.F.: Man and Biosphere Program UNESCO, Mexico, 177 p.

HALFFTER GAND FAVILA ME. 1993. The Scarabaeidae (Insecta: Coleoptera) an animal group for analyzing, inventorying and monitoring biodiversity in tropical rainforest and modified landscapes. Biol Int 27: 15-21.

Halffter G, Favila ME AND HalfFter V. 1992. A comparative study of the structure of the scarab guild in Mexican tropical rain forests and derived ecosystems. Folia Entomol Mex 84: 131-156.

HALFFter G AND MATTHEWs EG. 1966. The natural history of dung beetles of the subfamily Scarabaeinae (Coleoptera: Scarabaeidae). Folia Entomol Mex 12/14: 1-312.

HAMMER O, HARPER DAT AND RYAN PD. 2001. PAST: Palaeontological Statistics software package for education and data analysis. Palaeont Electr 4: 1-9.
HANSKI I AND CAMBEFORT Y. 1991. Competition in dung beetles. In: HANSKI I AND CAMBEFORT Y (Eds), Dung beetle ecology, Princeton: Princeton University Press, USA, p. 305-329.

HERnÁNDEZ MIM. 2007. Besouros escarabeíneos (Coleoptera: Scarabaeidae) da Caatinga paraibana, Brasil. Oecologia Brasiliensis 11: 356-364.

HERnÁNDEZ MIM AND VAZ-DE-MELlo FZ. 2009. Seasonal and spatial species richness variation of dung beetle (Coleoptera, Scarabaeidae s. str.) in the Atlantic Forest of southeastern Brazil. Rev Bras Entomol 53: 607-613.

HulBerT SH. 1971. Nonconcept of species diversity: A critique and alternative parameters. Ecology 52: 577-586.

INSTITUTO BRASILEIRO DE GEOGRAFIA E ESTATÍSTICA. 2009. Mapas Interativos: Biomas. Disponível em: http://mapas. ibge.gov.br/biomas2/viewer.htm. Accessed on 28 June 2009.

INSTITUTO BRASILEIRO DE GEOGRAFIA E ESTATÍsTICA. 2010. Cidades: Santa Maria, RS. Available at: http://www.ibge. gov.br/cidadesat/painel/painel.php? codmun=431690. Accessed on 13 August 2010.

Instituto Nacional de Meteorologia. 2010. Gráficos Estação Santa Maria, RS. Available at: http://www.inmet. gov.br/html/observacoes.php?lnk=Graficos. Accessed on 04 September 2010.

INVENTÁRIO FLORESTAL CONTÍNUO. 2010. Inventário Florestal Contínuo - RS. Available at: http://coralx.ufsm.br/ifcrs/ index.php. Accessed on 16 August 2010.

KLEIN BC. 1989. Effects of forest fragmentation on dung and carrion beetle communities in central Amazonia. Ecology 70: $1715-1725$.

Koller WW, Gomes A, Rodrigues SR AND Goiozo PFI. 2007. Scarabaeidae e Aphodiidae coprófagos em pastagens cultivadas em área do cerrado sul-mato-grossense. Rev Bras Zooc 9: 81-93.

LARSEN TH AND ForSYTH A. 2005. Trap spacing and transect design for dung beetle biodiversity studies. Biotropica 37: 322-325.

Link D, BIEZANKo C, TARRAGÓ MF AND CARVALHO S. 1977. Lepidoptera de Santa Maria e arredores. II. Morphidae e Brassolidae. Rev Centro Ciências Rurais 7: 381-389.

Lobo JM, MARTín-PIERA F AND VEIGA CM. 1988. Las trampas pitfall con sebo, sus posibilidades en el estudio de las comunidades coprófagas de Scarabaeoidea (Col.). I. Características determinantes de su capacidad de captura. Rev Ecol Biol Sol 25: 77-100.

LOPES J, CHOCHON I, YUZAWA SK AND KURNLEIN RRC. 1994. Entomofauna do Parque Estadual Mata dos Godoy: II. Scarabaeidae (Coleoptera) coletados em armadilhas de solo. Semina 15: 121-127.

LOPES J, KoRASAKi V, CATELli LL, MARÇAL VVM AND NUNES MPBP. 2011. A comparison of dung beetle assemblage structure (Coleoptera: Scarabaeidae: Scarabaeinae) between an Atlantic forest fragment and adjacent abandoned pasture in Paraná, Brazil. Zoologia 28: 72-79. 
LOUZADA JNC AND LOPES FS. 1997. A comunidade de Scarabaeidae copro-necrófagos (Coleoptera) de um fragmento de Mata Atlântica. Rev Bras Entomol 41: 117-121.

LOUZADA JNC, LOPES FS AND VAZ-DE-MELLO FZ. 2007. Structure and composition of a dung beetle community (Coleoptera, Scarabaeinae) in a small forest patch from Brazilian Pantanal. Rev Bras Zooc 9: 199-203.

LOUZADA JNC AND SILVA PRC. 2009. Utilisation of introduced Brazilian pastures ecosystems by native dung beetles: diversity patterns and resource use. Ins Conserv Divers 2: $45-52$

MACHADO PFS AND LONGHI SJ. 1990. Aspectos florísticos e fitossociológicos do "Morro do Elefante", Santa Maria, RS. Rev Centro Ciências Rurais 20: 261-280.

Madruga PRA, Illana VB, Kleinpaul JJ, Scapini GP, Berger G AND SALBEGO AG. 2007. Quantificação da cobertura florestal do campus da Universidade Federal de Santa Maria, com o auxílio de imagem de alta resolução. Ambiência 3: 79-88.

MAGURRAN AE. 1988. Ecological diversity and its measurement. New Jersey: Princeton University Press, USA, 192 p.

MARCHIORI JNC. 2009. A vegetação em Santa Maria. Ciência \& Ambiente 38: 93-112.

Marques AAB, Fontana CS, VÉlez E, BENCKE GA, SCHNEIDER M AND REIS RS. 2002. Lista de Referência da Fauna Ameaçada de Extinção no Rio Grande do Sul, Decreto $n^{\circ} 41.672$, de 10 de junho de 2002. Porto Alegre: FZB/MCT-PUCRS/PANGEA, Brasil, $52 \mathrm{p}$.

Martínez NJ, García H, PUlido LA, OsPinO D AND NARVÁEZ JC. 2009. Escarabajos coprófagos (Coleoptera: Scarabaeinae) de la Vertiente Noroccidental, Sierra Nevada de Santa Marta, Colombia. Neotrop Entomol 38: 708-715.

MATAVELLI RA AND LOUZADA JNC. 2008. Invasão de áreas de savana intra-amazônicas por Digitonthophagus gazella (Fabricius, 1787) (Insecta: Coleoptera: Scarabaeidae). Acta Amazonica 38: 153-158.

McGeoch MA, Rensburg BJV And Botes A. 2002. The verification and application of bioindicators: a case study of dung beetles in a savanna ecosystem. J Appl Ecol 39: 661-672.

MEDRI IM AND Lopes J. 2001. Scarabaeidae (Coleoptera) do Parque Estadual Mata dos Godoy e de área de pastagem, no norte do Paraná, Brasil. Rev Bras Zool 18: 135-141.

Milhomem MS, VAZ-DE-Mello FZ AND DinIZ IR. 2003. Técnicas de coleta de besouros copronecrófagos no Cerrado. Rev Agropec Bras 38: 1249-1256.

MitTermeier RA, GIL PR, HofFmanN M, Pilgrim J, BROOKS T, MitTERMEIER CG, LAMOREUX J AND FONSİA GAB. 2005. Hotspots revisited: earth's biologically richest and most endangered terrestrial ecoregions. Mexico D.F. CEMEX, Mexico, $392 \mathrm{p}$.

Morelli E, GonZÁlez-VAiner P AND BAZ A. 2002 Coprophagous beetles (Coleoptera: Scarabaeoidea) in Uruguayan Prairies: abundance, diversity and seasonal occurrence. St Neotropl Fauna Environ 37: 53-57.
MORENO CF. 2001. Métodos para medir la biodiversidad, MandT-Manuales and Tesis SEA. vol. 1. Zaragoza: Gorfi, Zaragoza, Spain, 84 p.

Moura LA. 2003. Coleópteros. In: FONTANA CS ET AL. (Eds), Livro Vermelho da Fauna Ameaçada de no Rio Grande do Sul, Porto Alegre: EDIPUCRS, Brasil, p. 85-94.

MourA LA. 2007. Coleópteros terrestres. In: BECKER FG ET AL. (Eds), Biodiversidade. Regiões da Lagoa do Casamento e dos Butiazais de Tapes, planície costeira do Rio Grande do Sul, Brasília: Ministério do Meio Ambiente/Fundação Zoobotânica do Rio Grande do Sul, Brasil, p. 210-229.

Myers N, MitTermeier RA, MitTermeier CG, Fonseca GAB AND KENT J. 2000. Biodiversity hotspots for conservation priorities. Nature 403: 853-858.

Nichols E, Larsen T, Spector S, Davis AL, Escobar F, FAVILA M AND VULINEC K. 2007. Global dung beetle response to tropical forest modification and fragmentation: A quantitative literature review and meta-analyses. Biol Conserv 137: 1-19.

Nichols E, Spector S, Louzada J, Larsen T, AmezQuita S AND FAVILA ME. 2008. Ecological functions and ecosystem services provided by Scarabaeinae dung beetles. Biol Conserv 141: 1461-1474.

Overbeck GE, Müller SC, Fidelis A, Pfadenhauer J, Pillar VP, BLANCO CC, BOLdRINI II, BOTH R AND ForNECK ED. 2009. Os Campos Sulinos: um bioma negligenciado. In: PILLAR VP ET AL. (Eds), Campos Sulinos - conservação e uso sustentável da biodiversidade, Brasília: Ministério do Meio Ambiente, Brasil, p. 24-41.

PeCK SB AND Forsyth A. 1982. Composition, structure, and competitive behaviour in a guild of Ecuadorian rain forest dung beetles (Coleoptera, Scarabaeidae). Can J Zool 60: 1624-1634.

Pell MC, Finlayson BL AND MCMahon TA. 2007. Updated world map of the Köppen-Geiger climate classification. Hydrol Earth Syst Sci 11: 1633-1644.

PEREIRA PRB, GARCIA-NetTo LR, BorIN CJA AND SARTORI MGB. 1989. Contribuição à geografia física do município de Santa Maria: unidades de paisagem. Geogr Ens Pesq 3: 37-68.

Roesch LFW, VieIRA FCB, PEREIRA VA, SchÜnEMANN AL, TeIXeIRA IF, SENNA AJT AND StefENON VM. 2009. The Brazilian Pampa: a fragile biome. Diversity 2009: 182-198.

SACKIS GD AND MORAIS ABB. 2008. Borboletas (Lepidoptera: Hesperioidea e Papilionoidea) do campus da Universidade Federal de Santa Maria, Rio Grande do Sul. Biota Neotrop 8: $151-158$.

SANTOS S. 2002. Crustáceo. In: ITAQUI J (Ed), Quarta Colônia de imigração Italiana: Inventários Técnicos. Flora e Fauna, Santa Maria: Condesus Quarta Colônia, Brasil, p. 193-198.

SANTOS TG, Kopp KL, SPIES MR, TREVISAN R AND CECHIN S 2005. Répteis do campus da Universidade Federal de Santa Maria, RS, Brasil. Biota Neotrop 5: 1-8. 
SAntos TG, Kopp K, SpIES MR, TREVISAN R And Cechin S. 2008a. Distribuição temporal e espacial de anuros em área de Pampa, Santa Maria, RS. Iheringia, Sér Zool 98: 244-253.

Santos TG, Spies MR, Kopp K, Trevisan R and Cechin S. 2008b. Mamíferos do campus da Universidade Federal de Santa Maria, Rio Grande do Sul, Brasil. Biota Neotrop 8: 125-131.

SCHOOLMEESTERS P, DAVIS ALV, EDMONDS WD, GILl B, Mann D, Moretto P, Price D, Reid C, Spector S AND VAZ-DE-Mello FZ. 2010. ScarabNet Global Taxon Database (version 1.5). Available at: http://216.73.243.70/ scarabnet/results.htm. Accessed on 16 August 2010.

Schwartz G AND Di MARE RA. 2001. Diversidade de quinze espécies de borboletas (Lepidoptera, Papilionidae) em sete comunidades de Santa Maria, RS. Ciência Rural 31: 49-55.

SILVA PG. 2011. Dung beetles (Coleoptera: Scarabaeidae: Scarabaeinae) of two non-native habitats in Bagé, Rio Grande do Sul, Brazil. Zool Stud 50: 546-559.

Silva PG, GARCIA MAR AND VidAL MB. 2008. Besouros copronecrófagos (Coleoptera: Scarabaeidae stricto sensu) coletados em ecótono natural de campo e mata em Bagé, RS. Ciência e Natura 30: 71-91.

Silva PG, GARCIA MAR AND VIDAL MB. 2009. Besouros copro-necrófagos (Coleoptera: Scarabaeidae sensu stricto) do município de Bagé, RS (Bioma Campos Sulinos). Biociências 17: 33-43.

Silva PG, VAZ-De-Mello FZ AND Di-Mare RA. 2012. Attractiveness of different bait to the Scarabaeinae (Coleoptera: Scarabaeidae) in forest fragments in extreme southern Brazil. Zool Stud 51: 429-441.

Silveira-Neto S, Nakano O, Barbin D and Villa-Nova NA. 1976. Manual de Ecologia dos Insetos. São Paulo: Agronômica Ceres, Brasil, 419 p.

SimMONS LW AND RIDSDILL-SMITH TJ. 2011. Reproductive competition and its impact on the evolution and ecology of dung beetles. In: SIMMONS LW AND RIDSDILLSMITH TJ (Eds), Ecology and evolution of dung beetles, Oxford: Blackwell Publishing Ltd., UK, p. 1-20.

SPECTOR S. 2002. Biogeographic crossroads as priority areas for biodiversity conservation. Conserv Biol 16: 1480-1487.

SPECTOR S. 2006. Scarabaeine dung beetles (Coleoptera: Scarabaeidae: Scarabaeinae): an invertebrate focal taxon for biodiversity research and conservation. Coleopt Bull 5: 71-83.

Spector S AND Ayzama S. 2003. Rapid turnover and edge effects in dung beetle assemblages (Scarabaeidae) at a Bolivian Neotropical forest-savanna ecotone. Biotropica 35: 394-404.
SPECTOR S AND FORSYTH AB. 1998. Indicator taxa for biodiversity assessment in the vanishing tropics. In: MACE GM ET AL. (Eds), Conservation in a Changing World, Cambridge: Cambridge University Press, UK, p. 181-209.

Tabarelli M, Pinto LP, Silva JMC, Hirota MM AND BEDÊ LC. 2005. Desafios e oportunidades para a conservação da biodiversidade na Mata Atlântica. Megadiversidade 1: $132-138$.

VAZ-DE-MeLlo FZ. 1999. Scarabaeidae s. str. (Coleoptera: Scarabaeoidea) de um fragmento de Floresta Amazônica no estado do Acre, Brasil. I. Taxocenose. An Soc Entomol Brasil 28: 447-453.

VAZ-DE-MELlo FZ. 2000. Estado de conhecimento dos Scarabaeidae s. str. (Coleoptera: Scarabaeoidea) do Brasil. In: MARTÍN-PIERA F ET AL. (Eds), Hacia un proyecto CYTED para el inventario y estimación de la diversidad entomológica en Iberoamérica, Zaragoza: Sociedad Entomológica Aragonesa, Zaragoza, Spain, p. 181-195.

VAZ-DE-MELLO FZ. 2007. Revision and phylogeny of the dung beetle genus Zonocopris Arrow 1932 (Coleoptera: Scarabaeidae: Scarabaeinae), a phoretic of land snails. Ann Soc Entomol Fr 43: 231-239.

VAZ-DE-MELlo FZ, EDMONDS WD, OCAMPO F AND SCHOOLMEESTERS P. 2011. A multilingual key to the genera and subgenera of the subfamily Scarabaeinae of the New World. Zootaxa 2854: 1-73.

VAZ-DE-Mello FZ AND GÉNIER F. 2009. Notes on the behavior of Dendropaemon Perty and Tetramereia Klages (Scarabaeidae: Scarabaeinae: Phanaeini). Coleopt Bull 63: 364-366.

VAZ-DE-MELlo FZ, GÉNIER F AND SMith ABT. 2010. Reclassification of Homocopris Burmeister as a valid genus to accommodate three species formerly in Dichotomius Hope (Scarabaeidae: Scarabaeinae: Coprini). Coleopt Bull 64: 192-192.

VAZ-DE-MELLO FZ, LOUZADA JNC AND SCHOEREDER JH. 1998. New data and comments on Scarabaeidae (Coleoptera: Scarabaeoidea) associated with Attini (Hymenoptera: Formicidae). Coleopt Bull 52: 209-216.

Verdú JR, Moreno CE, SÁnchez-Rojas G, Numa C, GALANTE E AND HALFFTER G. 2007. Grazing promotes dung beetle diversity in the xeric landscape of a Mexican Biosphere Reserve. Biol Conserv 140: 308-317.

WATERHOUSE DF. 1974. The biological control of dung. Sci Am 230: 100-109.

WoLDA H. 1988. Insect seasonality: Why? Ann Rev Ecol Syst 19: 1-18. 